\title{
Hubungan Kadar Timbel dalam Darah dengan Kadar Hemoglobin dan Hematokrit pada Petugas Pintu Tol Jagorawi
}

\section{The Correlation of Lead in Blood and Haemoglobin Concentration and Hematocrit Value of Toll Booth Workers at Jagorawi}

\author{
Tan Malaka* Meiri Iryani***
}

*Bagian Ilmu Kesehatan Masyarakat Kedokteran Komunitas Fakultas Kedokteran Universitas Sriwijaya, **Sekolah Tinggi Ilmu Kesehatan Bina Husada

\begin{abstract}
Abstrak
Penelitian tentang hubungan antara kadar timbel dalam darah dengan anemia yang tercermin dalam kadar hemoglobin dan hematokrit pada petugas pintu tol Jagorawi Jakarta. Landasan teori penelitian ini adalah hasil pemantauan kualitas udara Daerah Khusus Ibu Kota (DKI) Jakarta dimana kadar timbel di udara ambien melebihi Baku Mutu Lingkungan (BML) dan adanya petunjuk literatur bahwa timbel memiliki pengaruh negatif terhadap sistem hemopoitik pada manusia. Seratus orang pekerja terpilih untuk penelitian ini. Sebanyak $12 \%$ dari pekerja yang merupakan subjek pada penelitian ini tergolong anemia berdasarkan kadar hemoglobin darah dan $10 \%$ anemia berdasarkan nilai hematokrit. Kadar timbel darah yang didapatkan pada penelitian ini adalah $20,1 \pm 1,1 \mu \mathrm{gr} \%$ dengan maksimum $22,9 \mu \mathrm{gr} \%$; dengan kadar hemoglobin sebesar $15,2 \pm 1,5 \mathrm{gr} \%$ minimum $9,9 \mathrm{gr} \%$; nilai hematokrit sebesar $45,2 \pm 4,4 \%$, minimum $30 \%$. Seluruh subjek memiliki nilai $\mathrm{Pb}$ darah di atas $10 \mu \mathrm{gr} \%$ termasuk 16 wanita dalam usia subur. Secara umum tidak ditemukan asosiasi yang bermakna antara kadar timbel darah terhadap kadar hemoglobin dan hematokrit. Asosiasi yang tidak bermakna antara kadar timbel darah terhadap kadar dan abnormalitas hemoglobin dan hematokrit bersesuaian dengan hasil studi peneliti lainnya yang menyatakan bahwa hubungan bersifat tidak bermakna pada kadar $\mathrm{Pb}$ darah di bawah $40 \mu \mathrm{gr} \%$.

Kata kunci: Timbel dalam darah, hemoglobin, hematokrit, baku mutu lingkungan
\end{abstract}

\section{Abstract}

A study on the association of lead in blood and haemoglobin and hematocrit value as a measure of anaemia among toll booth workers at Jagorawi Jakarta, has been conducted. The rational of the study is that high aerial lead content has been reported by the Jakarta environmental authority and health literature indicates that lead is toxic to human hemopoeitic system. The toll booth workers are exposed to air pollutants in their day to day work. One hundred workers, randomly selected, participated in the study. On the haemoglobin concentration, $12 \%$ of the study subjects were categorized as anaemia, while on hematocrit values $10 \%$ were considered as anaemia. Blood lead concentrations found in this study were 20,1 $\pm 1,1$ (mean \pm SD) $\mu \mathrm{gr} \%$ and the maximum value was $22,9 \mu \mathrm{gr} \%$. The haemoglobin values were $15,2 \pm 1,5 \mathrm{gr} \%$ with a minimum of $9,9 \mathrm{gr} \%$, while the hematocrit values were $45,2 \pm 4,4 \%$ with a minimum of $30 \%$. All blood lead values were above $10 \mu \mathrm{gr} \%$ including 16 women of child-bearing age. In general, no association was found between blood lead and haemoglobin and hematocrit values. This discovery is in line with other studies which found that there is no meaningful association between blood lead and anaemia when the blood lead concentrations were below $40 \mu \mathrm{gr} \%$.

Key words: Blood lead, haemoglobin, hematocrit, environmental quality standards

\section{Pendahuluan}

Pencemaran atau polusi udara akibat buangan yang dikeluarkan dari knalpot kendaraan bermotor sangat berbahaya bagi kesehatan manusia. Asap kendaraan bermotor mengandung zat-zat kimia yang dapat mengganggu keseimbangan metabolisme dalam tubuh manusia, antara lain karbon monoksida $(\mathrm{CO})$, nitrogen oksida (NOx), dan timbel $(\mathrm{Pb})$. Zat-zat yang keluar dari knalpot dalam bentuk gas, terbuang ke udara kemudian bersenyawa dengan berbagai polutan sehingga konsentrasi udara terganggu dan terjadi pencemaran udara yang mengganggu kesehatan manusia. Peningkatan jumlah kendaran dan peningkatan bilangan oktan bensin menambah pencemaran timbel di udara. ${ }^{1}$ Hal ini dise-

Alamat Korespondensi: Tan Malaka, IKM-KK FK Universitas Sriwijaya, Kompleks RSU Moh. Husein Palembang, Hp. 08161351533,

e-mail: tanmalaka2002@yahoo.com 
babkan oleh bahan bakar minyak diberi oktan yang mengandung timbel untuk menyempurnakan pembakaran. ${ }^{2}$

Kadar timbel di Jakarta rata-rata mencapai 0,5 $\mu \mathrm{gr} / \mathrm{m}^{3}$. Kawasan tertentu seperti terminal bus dan daerah padat lalu lintas, kadar timbel dapat mencapai 2$8 \mu \mathrm{gr} / \mathrm{m}^{3}$. Daerah pemukiman di Jakarta, kadar timbel di udara pada tahun 1994-1998 mencapai 0,2-1,8 $\mu \mathrm{gr} / \mathrm{m}^{3}$. Kadar timbel udara bervariasi di pedesaan, biasanya kurang dari $1 \mu \mathrm{gr} / \mathrm{m}^{3}$ dan mampu mencapai lebih dari 10 $\mu \mathrm{gr} / \mathrm{m}^{3}$ di daerah perkotaan dan daerah urban. Sedangkan menurut penelitian Jakarta Urban Development Project, konsentrasi timbel di Jakarta mencapai $1,7-5 \mu \mathrm{gr} / \mathrm{m}^{3}$ pada tahun 2000.

Keberadaan timbel dalam tubuh dapat mengganggu sistem hemopitik pada sintese heme melalui tiga mekanisme, yakni mengganggu penyatuan Glycine dan Succinyl Co-Enzyme A, melalui depresi terhadap delta$A L A D$, dan melalui gangguan terhadap enzim Ferrochelatase yang berfungsi melekatkan besi $(\mathrm{Fe})$ terhadap protoporphyrin yang kemudian menjadi heme sebagai bagian dari hemoglobin. ${ }^{3}$ Tujuan penelitian ini untuk mengetahui kadar timbel di udara serta hubungan antara kadar timbel dalam darah dan faktor lain dengan kejadian anemia pada petugas pintu tol Jagorawi Jakarta tahun 2009.

\section{Metode}

Penelitian ini menggunakan desain penelitian survei analitik cross sectional, dimana data dikumpulkan secara bersamaan antara konsentrasi timbel dalam darah serta kadar hemoglobin dan hematokrit pada pekerja jalan tol Jagorawi. Pengambilan informasi dengan menggunakan kuesioner mengenai ciri demografik para pekerja yang terpilih. Lokasi penelitian dilakukan pada petugas di pintu tol dan petugas inspeksi jalan tol Jagorawi yang bertugas di Taman Mini Jakarta. Penelitian dilaksanakan pada bulan Agustus tahun 2009. Populasi penelitian adalah petugas pintu tol Jagorawi PT Jasa Marga Jakarta. Jumlah petugas pintu tol Jagorawi PT Jasa Marga Jakarta dengan jumlah pekerja yang telah bertugas setahun atau lebih sebanyak 200 orang. Berdasarkan perhitungan statistik dengan margin of error sebesar $10 \%$, didapatkan jumlah sampel sebanyak 68 orang. Namun pada penelitian ini, diambil jumlah yang lebih besar yakni setelah dilakukan data cleaning ternyata sampel yang dapat dianalisis sebanyak 100 orang dan diambil secara acak dari populasi.

\section{Hasil}

\section{Kadar Timbel di Udara}

Kadar timbel di udara Daerah Khusus Ibu Kota (DKI) Jakarta didapatkan dari data sekunder yang merujuk kepada beberapa data dan informasi serta hasil kunjungan ke Biro Lingkungan Hidup Pemerintah Daerah DKI tahun 2009. Hasil deskripsi statistik variabel numerik berupa umur pekerja, masa kerja, kadar hemoglobin, kadar hematokrit, dan kadar timbel dalam darah meliputi nilai rentang (kisaran), median, modus, nilai rata-rata, standar deviasi, dan variansi untuk masingmasing variabel numerik. Variabel independen umur pekerja terentang pada nilai 22-55 tahun dengan ratarata umur pekerja 38 tahun dengan nilai modus berumur 32 tahun. Variabel masa kerja didapat rata-rata 5 tahun dengan lama minimal 2 tahun dan maksimal 8 tahun. Nilai kadar hemoglobin rata-rata $(15,2$ gr\%) dengan hemoglobin terkecil $(9,9 \mathrm{gr} \%)$ dan terbesar $(17,9 \mathrm{gr} \%)$. Nilai kadar hematokrit didapatkan rata-rata 45,2\%, minimum $30 \%$, dan maksimum $57 \%$. Variabel timbel dalam darah, rata-rata pekerja mempunyai kadar timbel 20,1 dengan nilai terendah 18,5 dan tertinggi $22,9 \mu \mathrm{gr} \%$ (Lihat Tabel 1).

Analisis korelasi sederhana antarvariabel kontinyu dan variabel umur berasosiasi secara bermakna dengan masa kerja. Kadar hemoglobin berkorelasi secara bermakna dengan hematokrit, sedangkan timbel dalam darah tidak berkorelasi secara bermakna dengan variabel lainnya (Lihat Tabel 2).

Uji perbedaan ( $t$-test) nilai hemoglobin dan hematokrit berdasarkan jenis kelamin pada semua subjek pekerja $(\mathrm{n}=100)$ memperlihatkan bahwa hemoglobin dan hematokrit pada pria dan wanita memang berbeda secara bermakna sesuai dengan literatur ilmu faal. Hal ini mengindikasikan bahwa data yang didapat memiliki validitas internal (Lihat Tabel 3).

Frekuensi abnormalitas hemoglobin dan hematokrit pada semua pekerja yang diteliti, frekuensi anemia berdasarkan nilai hemoglobin adalah $12 \%$, sedangkan anemia berdasarkan nilai hematokrit adalah $10 \%$. Anemia yang terjadi pada para pekerja dapat disebabkan oleh berbagai faktor selain timbel, misalnya gangguan nutrisi atau pendarahan kronik, infeksi (misalnya malaria), dan lain-lain. Untuk memastikan peranan dari timbel terhadap anemia, diperlukan pemeriksaan yang spesifik kadar Zn protoporphyrin sesuai petunjuk Occupational Safety and Health Administration (OSHA). Pekerja terpapar timbel wajib dipantau timbel darah dan Zn protoporphyrin. Namun, pemeriksaan tersebut tidak dilakukan pada penelitian ini (Lihat Tabel 4 dan 5).

\section{Hubungan Timbel terhadap Hemoglobin dan Hematokrit}

Hubungan hemoglobin dan hematokrit darah para pekerja (sampel) terhadap kandungan timbel (dalam darah) merupakan kajian dan interes utama pada penelitian ini. Hal ini didasarkan pada premis bahwa timbel bersifat toksik terhadap sintese heme. Oleh karena itu, merupakan hal penting untuk diteliti, sedangkan dalam 
Tabel 1. Statistik Deskriptif Variabel Kontinyu $(\mathrm{n}=100)$

\begin{tabular}{|c|c|c|c|c|c|c|}
\hline Variabel & Kisaran & Median & Modus & Rata-rata & Standar Deviasi & Variansi \\
\hline Umur (tahun) & $22-55$ & 36 & 32 & 38,0 & 7,1 & 50,8 \\
\hline Masa kerja (tahun) & $2-8$ & 5 & 4 & 5,0 & 1,5 & 2,2 \\
\hline Hemoglobin (gr/\%) & $9,9-17,9$ & 15,3 & 15,6 & 15,2 & 1,5 & 2,2 \\
\hline Hematokrit (\%) & $30-57$ & 46 & 48 & 45,2 & 4,4 & 19,3 \\
\hline Timbel ( $\mu \mathrm{gr} \%)$ & $18,5-22,9$ & 20,21 & 20,2 & 20,1 & 1,1 & 1,2 \\
\hline
\end{tabular}

Tabel 2. Hasil Analisis Korelasi Sederhana (r) antarvariabel Kontinyu (Pearson's Correlation)

\begin{tabular}{|c|c|c|c|c|c|}
\hline Variabel & Umur & Masa Kerja & Hemoglobin & Hematokrit & Timbel \\
\hline Umur (tahun) & 1 & $0,981^{\text {*** }}$ & $-0,100$ & $-0,077$ & $-0,151$ \\
\hline Masa kerja (tahun) & $0,981^{* * *}$ & 1 & $-0,086$ & $-0,070$ & $-0,137$ \\
\hline Hemoglobin (gr\%) & $-0,100$ & $-0,086$ & 1 & $0,912^{* * * *}$ & 0,085 \\
\hline Hematokrit $(\%)$ & $-0,077$ & $-0,070$ & $0,912^{* * *}$ & 1 & 0,071 \\
\hline Timbel $(\mu \mathrm{gr} \%)$ & $-0,151$ & $-0,137$ & 0,085 & 0,071 & 1 \\
\hline
\end{tabular}

*Correlation is significant at the 0,05 level

**:Correlation is significant at the 0,01 level

darah terdeteksi kadar timbel anorganik yang menggambarkan adanya pemaparan. Kadar timbel dalam darah yang didapatkan pada penelitian ini berkisar antara 18,5 $\mu \mathrm{gr} \%-22,9 \mu \mathrm{gr} \%$ (standar deviasi $=1,1$ ) dengan ratarata sebesar $20,1 \mu \mathrm{gr} \%$.

Hubungan kadar timbel, hemoglobin, dan hematokrit pekerja berdasarkan hasil uji statistik regresi sederhana (simple regression) pada analisis bivariat menunjukkan bahwa kadar timbel berkorelasi positif dengan kadar hemoglobin dan hematokrit dengan koefisien korelasi (r) masing-masing sebesar 0,085 (hemoglobin) dan 0,071 (hematokrit). Hasil ini menunjukkan bahwa semakin meningkat kadar timbel akan menyebabkan semakin meningkat kadar hemoglobin dan hematokrit pekerja. Namun bila dilihat nilai signifikannya, timbel darah terhadap hemoglobin dan hematokrit tidak bermakna pada derajat $\mathrm{p}=0,05$.

Selanjutnya, untuk melihat pengaruh timbel darah terhadap hemoglobin dan hematokrit dengan mengendalikan pengaruh variabel lain berupa umur, masa kerja, jenis kelamin, dan merokok pada saat yang sama maka dilakukan uji regresi linier berganda (Lihat Tabel 5). Model yang digunakan, hemoglobin dan hematokrit dimasukkan dalam persamaan sebagai variabel dependen yang bersifat kontinyu. Dilihat dari partial koefisien regresi timbel terhadap hemoglobin yaitu Beta $=$ 0,063 dengan nilai $p=0,592$; sedangkan partial koefisien timbel terhadap hematokrit yaitu Beta $=0,148$ dengan nilai $\mathrm{p}=0,674$ (tidak signifikan). Walaupun timbal darah tidak mempengaruhi secara bermakna variasi hemoglobin dan hematokrit pada para pekerja, model yang digunakan memberikan $\mathrm{R}$ square yang cukup tinggi, masing-masing model sebesar $29 \%$. Hal ini terjadi karena pengaruh variabel jenis kelamin.

Analisis pengaruh timbel darah terhadap abnormalitas hemoglobin dan hematokrit pekerja dilakukan menggunakan model regresi logistik ganda dengan memasukkan hemoglobin dan hematokrit dalam persamaan sebagai normal-abnormal (variabel kategorikal). Hal ini menghasilkan nilai partial koefisien regresi antara kadar timbel terhadap hemoglobin dan hematokrit pekerja masing-masing, yaitu Beta $=0,049$ dengan $\mathrm{p}=0,871$ terhadap hemoglobin, Beta $=0,386$ dengan $\mathrm{p}=0,267$ terhadap hematokrit. Hasil ini menyatakan tidak terdapat pengaruh yang bermakna pada tingkat signifikansi 0,05. Dengan kata lain, abnormalitas hemoglobin dan hematokrit tidak terlihat sebagai pengaruh timbel darah. Hal ini mungkin terjadi karena kadar timbel yang ditemukan pada penelitian ini semuanya masih dibawah Biological Exposure Index American Conference on Governmental Industrial Hygienists (ACGIH) 2010 sebesar $30 \mu \mathrm{gr} \%$. Walaupun demikian, kadar yang didapat berada diatas nilai yang dapat dianggap background level yakni lebih tinggi dari $1,78 \mu \mathrm{gr} \%$ untuk pria dan $1,19 \mu \mathrm{gr} \%$ untuk wanita. Literatur yang lebih lama disebutkan bahwa background level adalah $25 \mu \mathrm{gr} \%-30 \mu \mathrm{gr} \%$ (Lihat Tabel 6).

\section{Pembahasan}

Kadar timbel dalam darah yang didapat pada penelitian ini terbilang cukup tinggi dibandingkan dengan Tugaswati dalam Hamonangan, ${ }^{4}$ dan Suciani, ${ }^{5}$ 
Tabel 3. Hasil Uji T Variabel Hemoglobin, Hematokrit, Timbel, Umur, dan Masa Kerja terhadap Jenis Kelamin

\begin{tabular}{|c|c|c|c|c|c|c|c|}
\hline Variabel & Jenis kelamin & $\mathbf{n}$ & Rata-rata & Standar Deviasi & Rata-rata Standar Eror & t & Nilai $p$ \\
\hline \multirow[t]{2}{*}{ Hemoglobin $(\mathrm{gr} \%)$} & Laki-laki & 84 & 15,4905 & 1,17654 & 0,12837 & 6,085 & 0,000 \\
\hline & Wanita & 16 & 13,4063 & 1,62541 & 0,40635 & & \\
\hline \multirow[t]{2}{*}{ Hematokrit (\%) } & Laki-laki & 84 & 46,1798 & 3,43633 & 0,37493 & 6,083 & 0,000 \\
\hline & Wanita & 16 & 39,9375 & 5,20857 & 1,30214 & & \\
\hline \multirow[t]{2}{*}{ Timbel $(\mu \mathrm{gr} \%)$} & Laki-laki & 84 & 20,1288 & 1,09922 & 0,11994 & 0,522 & 0,603 \\
\hline & Wanita & 16 & 19,9706 & 1,16763 & 0,29191 & & \\
\hline \multirow[t]{2}{*}{ Umur (tahun) } & Laki-laki & 84 & 38,13 & 7,277 & 0,794 & 0,419 & 0,676 \\
\hline & Wanita & 16 & 37,31 & 6,447 & 1,612 & & \\
\hline \multirow[t]{2}{*}{ Masa kerja (tahun) } & Laki-laki & 84 & 5,07 & 1,495 & 0,163 & 0,642 & 0,522 \\
\hline & Wanita & 16 & 4,81 & 1,377 & 0,344 & & \\
\hline
\end{tabular}

Tabel 4. Hasil Uji T Variabel Hemoglobin, Hematokrit, Timbel, Umur, dan Masa Kerja terhadap Kebiasaan Merokok

\begin{tabular}{|c|c|c|c|c|c|c|c|}
\hline Variabel & Rokok & $\mathbf{n}$ & Rata-rata & Standar Deviasi & Rata-rata Standar Eror & t & Nilai $p$ \\
\hline \multirow[t]{2}{*}{ Hemoglobin $(\mathrm{gr} \%)$} & Tidak merokok & 54 & 15,2648 & 1,21471 & 0,1653 & \multirow[t]{2}{*}{0,795} & \multirow[t]{2}{*}{0,428} \\
\hline & Merokok & 46 & 15,0304 & 1,72135 & 0,2538 & & \\
\hline \multirow[t]{2}{*}{ Hematokrit (\%) } & Tidak merokok & 54 & 45,5204 & 3,50037 & 0,4763 & \multirow[t]{2}{*}{0,836} & \multirow[t]{2}{*}{0,405} \\
\hline & Merokok & 46 & 44,7826 & 5,26588 & 0,7764 & & \\
\hline \multirow[t]{2}{*}{ Timbel ( $\mu g r \%)$} & Tidak merokok & 54 & 20,1911 & 1,13520 & 0,1545 & \multirow[t]{2}{*}{0,810} & \multirow[t]{2}{*}{0,421} \\
\hline & Merokok & 46 & 20,0007 & 1,07367 & 0,1583 & & \\
\hline \multirow[t]{2}{*}{ Umur (tahun) } & Tidak merokok & 54 & 38.69 & 7,394 & 1,006 & \multirow[t]{2}{*}{1,042} & \multirow[t]{2}{*}{0,300} \\
\hline & Merokok & 46 & 37,20 & 6,791 & 1,001 & & \\
\hline \multirow[t]{2}{*}{ Masa kerja (tahun) } & Tidak merokok & 54 & 5,19 & 1,530 & 0,208 & \multirow[t]{2}{*}{1,143} & \multirow[t]{2}{*}{0,256} \\
\hline & Merokok & 46 & 4,85 & 1,398 & 0,206 & & \\
\hline
\end{tabular}

dan jauh lebih rendah dari data Achmadi 1989,6. Perlu ditekankan bahwa walaupun kadar timbel di udara telah turun akibat pemakaian bensin tanpa timbel, namun kadar timbel dalam darah tidak serta-merta turun atau rendah. Hal ini terutama disebabkan oleh mobilisasi timbel dari jaringan (bone deposit) terutama pada mereka yang memiliki body burden yang tinggi akibat pemaparan di masa lampau. ${ }^{7,8}$

Sebagai best practice untuk kadar timbel di udara lingkungan kerja, para praktisi kesehatan kerja umumnya menggunakan rujukan ACGIH dan OSHA yang menetapkan standar untuk timbel di udara lingkungan kerja sebesar $50 \mu \mathrm{gr} / \mathrm{m}^{3} .{ }^{9-11} \mathrm{Hal}$ ini juga sesuai dengan TLV-TWA ACGIH, ${ }^{9}$. Untuk timbel dalam darah para pekerja, sebagai best practice dapat digunakan nilai rujukan (reference value) ACGIH, ${ }^{9}$ yang menetapkan Biological Exposure Index (BEI) untuk timbel sebesar 30 $\mu \mathrm{gr} \%$. Namun ACGIH, ${ }^{9}$ memberi catatan bahwa untuk wanita dalam usia subur, apabila kandungan timbel darah melebihi $10 \mu \mathrm{gr} \%$, dapat melahirkan anak dengan risiko kelainan kognitif. Data yang dicatat pada penelitian ini terdapat 16 orang wanita dengan usia subur (child bearing age) dengan kadar timbel dalam darah diatas $10 \mu \mathrm{gr} \%$.
Menurut OSHA, ${ }^{11}$ apabila kadar timbel di udara lingkungan kerja mencapai $40 \mu \mathrm{gr} / \mathrm{m}^{3}$ dan pekerja terpapar selama 30 hari atau lebih maka wajib dilakukan surveilans kesehatan. Surveilans kesehatan tersebut meliputi pemeriksaan darah termasuk timbel dan zinc protoporphyrin (ZPP). Apabila pemaparan terhadap timbel cukup rendah, yakni dibawah $40 \mu \mathrm{gr} \%$ dalam darah maka pemantauan dilakukan setiap 6 bulan. Apabila timbel darah seorang pekerja mencapai lebih dari $40 \mu \mathrm{gr} \%$ maka wajib dilakukan pemantauan setiap 2 bulan hingga menurun kurang dari $40 \mu g r \%$. Apabila kadar timbel dalam darah mencapai $60 \mu \mathrm{gr} \%$ atau lebih maka US-OSHA, ${ }^{11}$ mengharuskan pekerja tersebut dipindahkan atau diistirahatkan kemudian dilakukan surveilans setiap bulan dan hanya boleh bekerja kembali setelah kadar timbel dalam darah turun di bawah 40 $\mu \mathrm{gr} \%$. Frekuensi abnormalitas hemoglobin dan hematokrit pada semua pekerja yang diteliti berdasarkan pada Berkow and Fletcher, 12 frekuensi anemia berdasarkan nilai hemoglobin adalah $12 \%$, sedangkan anemia berdasarkan nilai hematoktit adalah $10 \%$. Untuk memastikan peranan timbel terhadap anemia, diperlukan pemeriksaan yang spesifik mengenai kadar Zn protoporphyrin sesuai petunjuk OSHA. Pekerja yang terpapar timbel wajib dipantau timbel darah dan $\mathrm{Zn}$ protopor- 
Tabel 5. Analisis Regresi Linier Ganda, Hemoglobin dan Hematokrit sebagai Variabel Dependen

\begin{tabular}{|c|c|c|c|c|}
\hline \multirow{2}{*}{$\begin{array}{l}\text { Variabel } \\
\text { Independen }\end{array}$} & \multicolumn{2}{|c|}{ Hemoglobin } & \multicolumn{2}{|c|}{ Hematokrit } \\
\hline & Beta & Nilai $p$ & Beta & Nilai $p$ \\
\hline Konstanta & 17,147 & 0,000 & 4,421 & 0,552 \\
\hline Umur (tahun) & $-0,021$ & 0,826 & $-0,091$ & 0,687 \\
\hline Masa kerja (tahun) & $-0,007$ & 0,987 & 0,077 & 0,944 \\
\hline Jenis kelamin & $-2,195$ & 0,000 & $-0,424$ & 0,644 \\
\hline Rokok & 0,243 & 0,368 & 0,613 & 0,392 \\
\hline $\mathrm{Pb}(\mu \mathrm{gr} \%)$ & 0,063 & 0,592 & 0,049 & 0,871 \\
\hline
\end{tabular}

R square $=0,297$

Kadar hemoglobin sebagai variabel kontinyu

Tabel 6. Hasil Analisis Regresi Logistik Ganda, Hemoglobin sebagai Variabel Dependen

\begin{tabular}{|c|c|c|c|c|c|c|}
\hline \multirow{2}{*}{ Variabel } & \multicolumn{2}{|c|}{ Variabel Dependen } & \multirow{2}{*}{$\begin{array}{c}\text { Hemoglobin } \\
\operatorname{Exp}(B)\end{array}$} & \multicolumn{2}{|c|}{ Variabel Dependen } & \multirow{2}{*}{$\begin{array}{c}\text { Hematokrit } \\
\operatorname{Exp}(\mathrm{B})\end{array}$} \\
\hline & Beta & Nilai p & & Beta & Nilai p & \\
\hline Umur & $-0,091$ & 0,687 & 0,913 & $-0,140$ & 0,559 & 0,870 \\
\hline Masa kerja (tahun) & 0,077 & 0,944 & 1,080 & 0,462 & 0,691 & 1,588 \\
\hline Jenis kelamin & $-0,424$ & 0,644 & 0,655 & $-0,720$ & 0,384 & 0,487 \\
\hline Rokok & 0,613 & 0,392 & 1,847 & $-0,439$ & 0,562 & 0,645 \\
\hline $\mathrm{Pb}(\mu \mathrm{gr} \%)$ & 0,049 & 0,871 & 1,050 & 0,386 & 0,267 & 1,471 \\
\hline Konstanta & 4,421 & 0,552 & 83,147 & $-1,345$ & 0,869 & 0,261 \\
\hline
\end{tabular}

Cox and Snell $R$ square $=0,041$

Nagelkerke $R$ square $=0,079$

Hemoglobin sebagai anemia atau nonanemia (dichotomous)

phyrin. Namun pada penelitian ini, pemeriksaan tersebut tidak dilakukan.

Kadar timbel dalam darah dan asosiasinya terhadap hemoglobin dan hematokrit merupakan tema utama dan merupakan hipotesis peneltian ini. Hal ini didasarkan pada landasan teoritis tentang pengaruh patologik timbel terhadap sistem haemopoeitic, khususnya pada biosintese heme. ${ }^{13}$ Pengaruh timbel terhadap sistem haemopoietic menyebabkan penurunan produksi red blood cell dan menurunnya waktu hidup (survival time) akibat gangguan pada membran sel. Sifat anemia yang terjadi adalah normochrom-normocytic atau normochrom-microcytic. Namun, kejadian pengaruh terhadap haemopoietic seperti di atas hanya terjadi pada pemaparan kronis dengan kadar timbel dalam darah 50 ugr\% atau lebih. Timbel menekan sintese heme melalui inhibisi enzim Ferochelatase, akibatnya terjadi peningkatan protoporphyrin dalam eritrosit. Hal ini dapat diuji dengan pemeriksaan Erythrocyte ZnProtoporphyrin (ZPP) dengan teknik Fluorometry. Selain itu, dapat dilakukan rangsangan dengan chelat berupa Ca-EDTA yang dapat memobilisasi timbel dari tulang sehingga terjadi ekskresi timbel dalam urine melampaui $600 \mu \mathrm{gr} / 24 \mathrm{jam}$. Pemeriksaan langsung timbel dalam tulang, misalnya tibia dan patella, dapat dilakukan dengan teknik X-Ray Flourescence (XRF) untuk melihat tingkat deposisi timbel dalam tulang. Timbel dalam tulang mencerminkan body burden. ${ }^{7}$

Telah banyak penelitian yang mencoba menghubungkan antara kadar timbel dalam darah dan penurunan kadar hemoglobin, mengingat teori yang menyatakan bahwa timbel dapat mengganggu biosintese heme. Hasil yang ada pada penelitian ini bersifat konsisten bahwa pada kadar timbel dalam darah dibawah $40 \mu \mathrm{gr} \%$, tidak terjadi gangguan pada hemoglobin. Data yang dihasilkan pada penelitian yang dilakukan saat ini, maksimum kadar timbel dalam darah adalah 22,89 $\mu \mathrm{gr} \%$. Oleh karena itu, tidak adanya asosiasi yang signifikan antara timbel darah dan hemoglobin seperti yang diperlihatkan pada analisis multivariat. Kenyataan ini juga sesuai dengan hasil penelitian Suciani, ${ }^{5}$ di Universitas Diponegoro yang melakukan pengamatan pada polisi lalu lintas (polantas) di Semarang.

Hubungan atau pengaruh timbel terhadap hematokrit didasarkan pada pengamatan bahwa kondisi anemia yang terjadi bersifat normochrom-microcytic atau normochrom-normocytic. ${ }^{7}$ Hasil rangkuman yang diberikan oleh Environmental Protection Agency (EPA) menya- 
takan bahwa pada kadar timbel dalam darah di bawah 40 $\mu \mathrm{gr} \%$ tidak terdapat asosiasi yang bermakna. Hubungan signifikan yang bersifat negatif umumnya terjadi pada kadar diatas $40 \mu \mathrm{gr} \%$. Hasil pengamatan yang ada pada penelitian ini ternyata memperlihatkan hubungan yang lemah atau tidak bermakna antara hematokrit dengan kadar timbel dalam darah. Oleh karena itu, data tersebut juga memberi konfirmasi pada temuan dan data sebelumnya yang dirangkum oleh EPA.

Ringkasan pengaruh timbel terhadap sistem haemopoeitic menurut literatur terkini adalah pengaruh mulai terlihat (observable) pada kadar $30 \mu \mathrm{gr} \%$. Penulis mencatat perbedaan data dan informasi ini dengan literatur lama yang umumnya memberikan angka 40 $\mu \mathrm{gr} \%-60 \mu \mathrm{gr} \%$. ACGIH, ${ }^{9}$ mengadopsi data ilmiah yang ada dan menetapkan angka $30 \mu \mathrm{gr} \%$ sebagai BEI dan merupakan rekomendasi best practice untuk para praktisi. Berdasarkan kajian literatur termasuk data dan informasi pada penelitian ini, dapat disimpulkan bahwa timbel dalam darah ditambah dengan ZPP darah merupakan best practice dalam melakukan penilaian risiko kesehatan para pekerja yang terpapar timbel.

Cara pemeriksaan lain adalah dengan menggunakan enzim delta-ALAD dalam urine, baik langsung atau setelah diprovokasi dengan chelat seperti Ca-EDTA. Kadar timbel dalam darah menggambarkan tingkat pemaparan yang terbaru, sedangkan ZPP menggambarkan body burden terhadap timbel yang sudah diserap lebih lama dan lebih stabil.3,7,9,11

Cara dan teknik pengendalian pemaparan terhadap timbel di udara lingkungan kerja dapat dirujuk pada petunjuk yang dikeluarkan OSHA. ${ }^{11} \mathrm{Hal}$ ini ditegaskan bahwa pendekatan terbaik adalah mengurangi atau menghilangkan pemaparan dengan memberlakukan penghentian pemakaian bensin yang bertimbal (leaded) dengan unleaded gasoline. Langkah ini merupakan pencegahan yang bersifat primer (primary prevention). Dalam kerangka primary prevention, pengendalian pajanan secara engineering yaitu melakukan perbaikan terhadap ventilasi tempat kerja operator pintu tol. Selain kedua pendekatan diatas, pihak PT Jasa Marga sebaiknya menerapkan program perlindungan pernapasan (Respiratory Protection Program, RPP). Best practice untuk RPP dapat mengacu pada petunjuk dan peraturan dari US-OSHA. ${ }^{11}$ Pendekatan kedua adalah melakukan pemantauan biologis (biological monitoring) dengan melakukan pemeriksaan timbel darah dan ZPP. Pendekatan ketiga adalah pemeriksaan kesehatan untuk melihat pengaruh multitarget dari timbel terutama terhadap darah (hematology), ginjal, dan saraf. ${ }^{3}$

\section{Kesimpulan}

Seluruh sampel memmpunyai nilai di atas $10 \mu \mathrm{gr} \%$, termasuk 16 wanita dalam usia subur. Secara umum tidak ditemukan asosiasi yang bermakna antara kadar timbel dalam darah terhadap kadar hemoglobin dan hematokrit. Pekerja yang merupakan subjek pada penelitian ini tergolong anemia, berdasarkan kadar hemoglobin darah (12\%) atau anemia berdasarkan nilai hematokrit $10 \%$. Masa kerja rata-rata dari sampel pekerja pada penelitian ini adalah 5 tahun dengan standard deviasi $=1,5$ tahun. Hasil analisis regresi berganda memperlihatkan bahwa variabel yang berpengaruh terhadap kadar hemoglobin dan volume hematokrit adalah jenis kelamin. Fakta ini sesuai dengan data ilmah yang didapat dalam ilmu faal dimana rata-rata hemoglobin dan hematokrit berbeda pada wanita dan pria, yakni pria lebih tinggi dari wanita. Asosiasi yang tidak bermakna antara kadar timbel dalam darah terhadap kadar dan abnormalitas hemoglobin dan hematokrit sesuai dengan kajian peneliti lain yang menyatakan bahwa hubungan bersifat tidak bermakna pada kadar hemoglobin di bawah $40 \mu g r \%$. Best practice tentang surveilans kesehatan pekerja yang terpapar timbel adalah pemeriksaan timbel darah, ZPP setiap enam bulan ditambah pemeriksaan kesehatan prajabatan dan berkala.

\section{Saran}

Penelitian lebih lanjut yang perlu dilakukan adalah penilaian risiko kesehatan pada wanita usia subur yang terpapar timbel dengan kadar di atas $10 \mu g r \%$. Penelitian lanjutan tentang pengaruh Polymorphism enzim ALAD terhadap anemia pada para pekerja terpapar timbel. Penelitian lanjutan tentang pengaruh gizi, khususnya elemen Fe dan kalsium terhadap kejadian anemia pada pekerja terpapar timbel. Sebaiknya, surveilans kesehatan pekerja terpapar timbel dibuatkan petunjuk yang jelas oleh Kementerian Tenaga Kerja RI dan Kementerian Kesehatan RI sehingga publik khususnya sektor industri dapat berpartisipasi secara optimal. Perusahaan PT Jasa Marga sebaiknya melakukan surveilans kesehatan dengan pemeriksaan timbel di lingkungan udara ambient, lingkungan kerja; biomonitoring yang terdiri dari timbel darah dan ZPP minimum 6 bulan sekali ditambah pemeriksaan kesehatan berkala serta menerapkan program perlindungan pernapasan.

\section{Daftar Pustaka}

1. Sastrawijaya A, Tresna. Pencemaran lingkungan. Jakarta: PT Rineka Cipta; 2000.

2. Chafid F, Kaharuddin, Mukhlison. Perhutanan kota. Yogyakarta: Fakultas Kehutanan Universitas Gadjah Mada; 2004.

3. Patrick L. Lead toxicity: a literature review, alternative medicine review. 2006; 11 (1).

4. Hamonangan E. Hasil pengukuran pb di udara ambien Kota Jakarta. Research Report JKPKBPPK. 2003 
5. Suciani S. Kadar timbal dalam darah polisi lalu lintas dan hubungannya dengan kadar hemoglobin [tesis]. Semarang: Universitas Diponegoro; 2009.

6. Achmadi UF. Analisis risiko efek pencemaran udara co dan pb terhadap penduduk Jakarta. Depok: Fakultas Kesehatan Masyarakat Universitas Indonesia; 1989.

7. Goldstein DM, Kipen HM. Hematologic disorders in occupational health recognizing and preventing work related disease and injury. Barry SL, David HW, editors. Philadelphia: Lippincott Williams and Wilkins; 2000.

8. Skerfving S. Criteria document for Swedish occupational standards: inorganic lead. Stockholm, Sweden: National Institute for Working Life; 2005.
9. ACGIH. American conference of governmental industrial hygienist: tlvbooklet 2009. Cincinnati: ACGIH; 2010.

10. Malaka T. Health risk assessment, theory, and application dalam kuliah pasca sarjana tentang K3-LH lanjut. Palembang: Sekolah Tinggi Ilmu Kesehatan Bina Husada; 2008.

11. US-OSHA. Regulations (standards-29 CFR), respiratory protection. 1910,134. 2008 [diakses tanggal 4 Januari 2010]. Diunduh dari: http://www,osha,gov/pls/oshaweb/owadisp,show_document?p_id=127 $16 \&$ p_table $=$ standards.

12. Berkow R, Fletcher AJ. Hematology and oncology (chapter 9). The Merck Manual. 16th ed. Rahway NJ: Merck Research Laboratory; 1992.

13. Harbison RD. Lead (chapter 19). Hamilton and Hardy's Industrial Toxicology. 5th ed. St Louis, Missouri: Mosby-Yearbook Inc; 1998. 